\title{
PRODUCTION STANDARDS AND THE QUALITY OF MILK AND MEAT PRODUCTS FROM CATTLE AND SHEEP RAISED IN SUSTAINABLE PRODUCTION SYSTEMS
}

\author{
S. Jovanović ${ }^{1}$, M. Savić ${ }^{1}$, S. Aleksić ${ }^{2}$, D. Živkovićn \\ ${ }^{1}$ Faculty of Veterinary medicine, Belgrade, Republic of Serbia \\ ${ }^{2}$ Institute for Animal Husbandry, Belgrade-Zemun, Republic of Serbia \\ ${ }^{3}$ The Christ College, Cincinnati, Ohio, USA \\ Corresponding author: mij@beotel.net \\ Invited paper
}

Abstract: Basic principles that inform organic livestock production are reviewed in this paper, with special emphasis on milk and meat production in cattle and sheep. Research findings to date are presented on the impact of various management practices, both organic and conventional, as they effect product yield and quality. The importance of incorporating autochnochous breeds into organic milk and meat production systems is particularly emphasized. Additionally, a global overview of organic milk and meat production is given, along with an assessment of opportunites for implementing organic production systems in Serbia.

Key words: organic production, milk quality, meat quality

\section{Introduction}

Organic animal breeding is inevitably and closely linked to those processes within sustainable rural development models, which ensure that natural resources are exploited while a balance is maintained with biodegradable reserves in a given habitat, and that these practices are also conducive to traditions inherent in the human populace. Therefore, organic farming incorporates all aspects of agriculture with respect to preservation and replenishment of natural resources, and the reemergence of traditional values and knowledge.

Strict implementation of defined standards and regulations, along with control measures at each stages of production, are characteristic of organic animal breeding compared to conventional methods. Simultaneously, these practice measures contribute to production of safe animal products, habitat preservation, and sustainable development of socio-economic communities. 
Implementation of the highest standards of animal welfare reflects positively on animal health and wellbeing. Consequently, the effects of organic animal production on human health and the environment are long-lasting and of incomparable value. However, organic production is also characterised by decreased productivity as compared to conventional systems that results in approximately a $30 \%$ higher market price for organic products. Well designed action plans that direct and support the development of organic production models at the national level, therefore, represent crucial components for this transition period.

\section{The importance of autochthonous breeds in organic livetock management}

Most recently, autochthonous breeds have been recognized as important elements to regional agro-biodiversity and, more specifically, in their relevance to agro-ecosystems that encompass the cultural heritage of a given region. By recognizing that locally adapted animal breeds have gained genetic resistance and adaptability through the evolutionary process, breeding strategies in sustainable and organic farming practices today are far more attuned to the necessity for preserving and utilizing these autochthonous breeds (FAODAD-IS, EURECA project, 2010). Locally adapted breeds can promote sustainable development, reduce production costs, and prevent genetic pollution of a region's biodiversity.

The significance of autochthonous breeds is especially stressed in the production of organic meat. To this point, advertising campaigns regularly deliver messages that highlight autochthonous, indigenous breeds, which is not only scientifically accurate from the aspect of environmental adaptation, but most importantly, builds consumer confidence in domestic products. In Great Britain, for example, Aberdeen Angus cattle are most frequently named in organic production systems, along with autochthonous breeds of sheep that have been raised traditionally in certain regions of the land. In Germany, the Wurttemberg breed is most frequently lauded in organic production systems. In our own country, there are numerous locally adapted autochthonous breeds from the lineage of Pramenka sheep that are conducive to organic production of meat and milk, such as: Sjenica, Svrljiška, Pirot i Lipa sheep (Jovanović et al., 2009, 2010; Savić et al.,2009, 2011). Regarding cows, the most suitable breeds for organic milk and meat production are crosses of the Simmental breed, which has long been raised in our specific environment. Investigations are currently underway to determine the advantages of introducing exotic breeds into organic production systems, specifically the Hereford for meat and the Holstein for milk (Aleksić et al., 2009). 


\section{Effects of management practice and nutritional protocols on milk and meat characteristics}

Investigations on the characteristics of animal products, namely milk and meat, indicate that differences do exist in both nutritional quality and taste between products raised in organic and conventional production systems (Butler et al., 2006; Leifert et al., 2007).

The results from these investigations show that the main factors impacting differences in the quality of animal products from organic or conventional systems are differences in breed, management systems, nutritional protocols, as well as the overall health and welfare of animals involved. As an example, the impact of management systems was compared as related to the quality of meat from lambs grazing on unimproved mountain range (over $1000 \mathrm{~m}$ above sea level) with meat from lambs on cultivated lowland pastures in Norway. This study showed a significant effect of pasture type on body conformation (lambs in the mountains may walk long distance), as compared to lambs confined to paddocks in the lowlands. A significant difference was recorded between the groups when grading fat content and fatty acid composition, meat colour, and flavour. Differences in sensory traits were, in general, small and most likely not noticed by the consumer (Andoy et al., 2005).

Welfare conditions for free ranging animals were superior to many indoor systems. One problem that was pointed out, however, in free ranging animals, involves efforts to improve protection from predator species, in particular wolves, lynx, and others that have resulted in increased sheep losses, while also causing considerably more pain and prolonged suffering than slaughter itself (Asheim et al., 2005).

The majority of studies indicate that, in various management systems, feeding regimens have the greatest impact on the composition of nutritionally relevant components in milk and meat (Leifert et al., 2007). Animal products with a high content of polyunsaturated fatty acids, conjugated linolenic acid (CLA), antioxidants, such as carotenoids, and vitamin E, are more preferable from a nutritional standpoint. Particular consideration was given to examining fatty acid composition and CLA content in milk and meat from organic and conventional systems. In many ways, these fatty acids are beneficial to human health, since they play an important role in protecting the organism from cardiovascular disease, as well as in prevention against certain types of malignant and autoimmune diseases, such as lupus, rheumatoid arthritis, etc. (Connor et al., 2009). 


\section{Organic milk}

Globally, milk production based on organic production principles, is exhibiting a tendency to increase, especially evident in the EU countries. Organic milk, compared with conventional milk, has a more favourable fatty-acid composition, containing more polyunsaturated fatty acids of the omega-3 group of fatty acids (Ellis et al., 2006; Prandini et al., 2009). Research shows that cow nutrition in organic farming, based on extensive use of pasture, has the highest effect on fatty-acid content of milk, as it increases the content of polyunsaturated fatty acids, especially omega- 3 fatty acids and CLA.

Apart from the advantages of fatty acid content, studies showed that organic milk also contains higher levels of certain vitamins, primarily $\alpha-$ tocopherol and vitamin A (Butler et al., 2006; Pentelescu et al., 2009).

Milk fat of cows whose nutrition was based on conserved food (silage), and concentrate, has a 4:1 ratio between omega- 6 and omega-3 fatty acids. In organic milk, the ratio between omega- 6 and omega- 3 fatty acids is lower, which may result from the way cows are fed in the organic farming systems, primarily on pasture. When compared to conventional milk, milk from organically raised cows with nutritional regimens that include pastures and a higher consumption of fresh grass, showed a higher content of vitamins $\mathrm{C}, \mathrm{A}$ and $\alpha$-tocopherol. Differences in the content of these vitamins between organic and conventional milk, however, were not considered to be statistically significant. In research conducted by Woese (1997), differences in vitamin E content between organic and conventional milk were not statistically significant either, although organic milk did show higher levels of vitamin E. Tangentially, other researches (Butler et al., 2006) did indicate that organic milk does contain substantially higher levels of the vitamin A and $\alpha-$ tocopherol as compared to conventional milk.

Results of investigations conducted in Serbia proved that milk produced in accordance with principles of organic production, had a higher content of polyunsaturated and omega-3 fatty acids throughout the entire examination period, when compared to conventional milk $(\mathrm{p}<0.01)$, while the greatest differences were recorded during the pasture season. Organic milk also showed a higher content of vitamins $\mathrm{A}, \mathrm{C}$ and $\alpha$-tocopherol as compared to conventional milk, although the difference was not statistically significant (Popović-Vranješ et al., 2011).

\section{Organic meat}

In recent years, the demand for organically produced meat has increased. Current studies report higher levels of nutritionally desirable compounds in meat from organic production systems compared to meat from conventional systems. Other studies have either reported no significant difference in composition between 
organic and conventional meat, or the results have been inconsistent. In a study by Walshe (2006), directed at determining the composition and sensory characteristics of the longissimus dorsi muscle from steers reared under organic and conventional production systems, it was confirmed that organic samples were significantly higher in fat content and significantly lower in moisture content compared to conventional samples. No significant differences were observed between conventional and organic samples for protein, ash, $\beta$-carotene, $\alpha$-tocopherol or retinol. There was also no significant difference in fatty acid content.

Being that lamb is one of the most sought after animal products in the marketplace today, an extensive study was undertaken in Great Britain to determine if there were any differences in the quality of meat raised under either organic or conventional production systems (Angood et al., 2008). Results from this study recorded the nutritional quality, fatty acid composition, and a sensory panel; data indicated that organic lamb had a better eating quality than conventional lamb in terms of juiciness, flavour and overall liking, thus providing some evidence for the perception among consumers that organic products "taste better". Differences in flavour were attributed to differences in fatty acid composition, in particular, the higher level of linolenic acid (18:3) and total n-3 PUFA in organic meat (Angood et al., 2008).

Bearing in mind that suckling lamb, raised exclusively on maternal milk from birth to slaughter, is an important commodity raised typically in Mediterranean areas, and that it yields a high-quality product of great economic significance for this region, a comparison of the sensory characteristics of suckling lamb meat from organic and conventional production systems has been conducted and the data evaluated (Revilla et al., 2009). Results obtained show that the appearance of organic meat was more fibrous, darker, and with a lower aroma intensity than the conventional counterpart, but with no differences in homogeneity or juiciness. In grilled meat, the organic samples had less subcutaneous fat, were less marbleized, had a less fibrous texture and less aroma intensity, and were also less juicy. When ranking overall consumer satisfaction, higher scores were given to the organically produced samples.

\section{Conclusion}

Most recent research findings on ruminant milk and meat products that were obtained under different management systems, indicate that certain differences do exist in product composition and quality. Most significantly, organic products recorded more favorable values for fatty acid composition, conjugated linolenic acid (CLA), antioxidants, such as the carotenoids, and vitamin E content. These differences are predominantly influenced by breed specificities, feeding regimens and husbandry methods. Additionally, organic products are considered to 
be safer for human consumption since organic production must adhere to strict regulatory measures regarding acceptible levels of compounds harmful to human health, such as synthetic fertilisers, pesticides, pharmaceutical products, or other medications. In conclusion, the specific characteristics of organic production models, which are based on the use of local resources, can have a significant impact on promoting development of individual regions themselves.

\section{Acknowledgment}

This research was conducted within the projects: TR 31085 and TR 31053 supported by the Ministry of Education and Science of the Republic of Serbia.

\section{Proizvodnja i kvalitet mleka i mesa goveda i ovaca u uslovima održive proizvodnje}

S. Jovanović, M. Savić, S. Aleksić, D. Živković

\section{Rezime}

$\mathrm{U}$ radu su prikazani osnovni principi organske proizvodnje u stočarstvu. Posebna pažnja posvećena je proizvodnji mleka i mesa goveda i ovaca. Prikazani su dosadašnji rezultati ispitivanja uticaja različitih uslova gajenja u organskoj i konvencionalnoj proizvodnji na prinos i kvalitet proizvoda. Istaknut je značaj korišćenja autohnonih rasa u organskoj proizvodnji mleka i mesa. Dat je prikaz organske proizvodnje mleka i mesa u svetu, kao i mogućnosti organizovanja organske proizvodnje $u$ našoj zemlji.

\section{References}

ANGODA K.M., WOODA J.D., NUTE G.R., WHITTINGTON, F.M., HUGHES S.I., SHEARD P.R. (2008): A comparison of organic and conventionally-produced lamb purchased from three major UK supermarkets: Price, eating quality and fatty acid composition. Meat Science, 78, 3, 176-184.

ANDOY T., HAUNG A., SORHEIM O., THOMASSEN M.S, VARSZEGI Z., EIK L.O. (2005): Grazing on mountain pastures does it affect meat quality in lambs? Livestock Production Science, 95, 25-31.

ASHEIM L.J., EIK L.O. (2005): Animal welfare condition for free ranging sheep in norvegiana predator habitats. Biotechnology in Animal Husbandry, 21, 5-6, 105-109. 
ALEKSIĆ S., PANTELIĆ V., RADOVIĆ Č. (2009): Livestock production - present situation and future development directions in Republic of Serbia. Biotechnology in Animal Husbandry, 25, 5-6, 267-276.

BUTLER G., STERGIDIS S., EYRNE M., LEIFERT C. (2006): Effect of production system and geographic location on milk quality parameters, Aspects of Applied Biology, 80, 189-193.

CONNOR W.E. (2009): Importance of $n-3$ fatty acids in health and disease. The American Journal of Clinical Nutrition, 71, 1, 171-175.

ELLIS K.A, INNOCENT G., GROVE -WHITE D., CRIPPS P., MC LEAN W.G., HOEARD C.V., MIHM M. (2006): Comparing the fatty acid composition of organic and conventional milk. Journal of Dairy Science, 89, 1938-1950.

JOVANOVIĆ S., SAVIĆ M., ŽIVKOVIĆ D. (2009): Genetic variation in diseases resistance among farm animals, Biotechnology in Animal Husbandry, 25, 5-6, 339347.

JOVANOVIĆ S., POPOVIĆ-VRANJEŠ A., VEGARA M., SAVIĆ M. (2009): The effects of sustainable dairy farming system on milk composition and quality. Book of Abstracts, $60^{\text {th }}$ EAAP, 287.

JOVANOVIĆ S,. SAVIĆ M., TRAILOVIĆ R. (2010): Principi organske proizvodnje u stočarstvu, Tradicija i budućnost stočarstva u brdskom podrucju sa posebnim osvrtom na sjeničko peštersku visoravan, Sjenica, 117-126.

LEIFERT C., REMBIALKOWSKA E., NIELSON J.H., COOPER, J.M., BUTLER G., LUECK L. (2007): Effects of organic and 'low input' production methods on food quality and safety. 3rd QLIF Congress: Improving Sustainability in Organic and Low Input Food Production Systems, Germany.

PENTELESCU N.O. (2009): Fatty acid, retinol and carotene content of organic milk. International Journal of the Bioflux Society, 1, 1, 21-26.

POPOVIĆ-VRANJEŠ A., SAVIĆ M., PEJANOVIĆ R., JOVANOVIĆ S., KRAINOVIĆ G. (2011): The effect of organic milk production on certain milk quality parameters, Acta Veterinaria (in press).

PRADINI A., SIGOLO S., PIVA G. (2009): Conjugated linoleic acid (CLA) and fatty acid composition of milk, curd and Grana Padano cheese in conventional and organic farming systems. Journal of Dairy Research, 76, 278-282.

REVILLA I., LURUENA-MARTINEZ M.A,. BLANCO-LOPRZ M.A,. VIVARQUINTANA A.M., PALACIOS C., SEVERIANO-PEREZ P. (2009): Comparison of the sensory characteristics of suckling lamb meat: organic vs conventional production. Czech J. Food Sci., 267-270.

SAVIĆ M., JOVANOVIĆ S,. VEGARA M., POPOVIĆ-VRANJEŠ A. (2009): Sustainable livestock production in Serbia mountain regions. Book of Abstracts, 60 ${ }^{\text {th }}$ EAAP, 502.

SAVIĆ M., JOVANOVIĆ S., TRAILOVIĆ R., DIMITRIJAVIĆ V., DIMITRIJAVIĆ B. (2011): Autochthonous breeds as livestock potential in sustainable and organic production in Serbia. $19^{\text {th }}$ International congress of 
Mediterranean federation of health and production of ruminants, Belgrade, Proceedings, 16-23.

WALSHE B.E., SHEEHAN E.M., DELAHUNTY C.M., MORRISSEY P.A., KERRY J.P. (2006): Composition, sensory and shelf life stability analyses of longissimus dorsi muscle from steers reared under organic and conventional production systems. Meat Science, 73, 2, 319-325.

WOESE K., LANGE D., BOESS C., BOGL K.W. (1997): A comparison of organically and conventionally grown foods - results of a review of the relevant literature. Journal of the Science of Food and Agriculture, 74, 281-293.

Received 30 June 2011; accepted for publication 15 August 2011 